\title{
Conversations from south of the equator: Challenges and Opportunities in OER across Broader Oceania
}

\author{
Rosalind James ${ }^{1}$ and Carina Bossu ${ }^{2}$ \\ 1. University of New England, Australia | directordehub@une.edu.au \\ 2. University of Tasmania, Australia | Carina.Bossu@utas.edu.au
}

Submitted in: June 2014

Accepted in: June 2014

Published in: July 2014

\section{Recommended citation}

James, R. \& Bossu, C. (2014). Conversations from south of the equator: Challenges and Opportunities in OER across Broader Oceania. RUSC. Universities and Knowledge Society Journal, 11(3). pp. 78-90. doi http://dx.doi.org/10.7238/rusc.v1 1 i3.2220

\begin{abstract}
Recent decades have witnessed a number of fundamental structural shifts, both internally within the higher education academy and external to it, that have transformed the character of universities. A universal, increased interest in Open Educational Resources (OER) is at once both one of these added pressures and perhaps potentially a key way to meet the growing demand for higher education. The overarching theme of this Special Section, OER initiatives in Broader Oceania, allows educators to showcase how challenges and opportunities in this region are being addressed with innovation and/or collaboration. It also facilitates sharing of knowledge and exchange of varied perspectives and dialogue, not only between countries in the region, but hopefully also between Broader Oceania and Europe. Developments and trends in OER and an emergent Open Educational Practice across AsiaPacific mirror advances occurring across the world.
\end{abstract}

\section{Keywords}

open educational resources, open educational practice, open access, open data, learning design, MOOC 


\section{Conversaciones desde el sur del ecuador: retos y oportunidades que plantean los REA en Oceanía}

\section{Resumen}

En las últimas décadas, se han producido una serie de cambios estructurales fundamentales (tanto internamente, en el seno de la educación superior, como fuera de ella) que han transformado el carácter de las universidades. El aumento del interés generalizado en los recursos educativos abiertos (REA) es, a la vez, una presión añadida a esos cambios y, quizá, también una clave potencial para dar respuesta a la demanda creciente de educación superior. En esta sección monográfica sobre las iniciativas en el ámbito de los REA en Oceanía, los docentes muestran cómo se están abordando los retos y las oportunidades en esta región a través de la innovación y/o la colaboración. Esta sección monográfica es, asimismo, un marco para la comunicación del conocimiento y el intercambio de distintos puntos de vista, además del diálogo, no solo entre los países de la región, sino también, posiblemente, entre Oceanía y Europa. Las últimas novedades y tendencias en IOS REA, así como la emergencia de las prácticas educativas abiertas (PEA) en la región Asia-Pacífico, son un fiel reflejo de los avances que se están produciendo en todo el mundo.

\section{Palabras clave}

recursos educativos abiertos, prácticas educativas abiertas, acceso libre, datos abiertos, diseño del aprendizaje, MOOC 


\section{Introduction}

Higher education institutions play a major role in societal development and wellbeing as well as national economic competitiveness in the current knowledge-based global economy. Yet, they are beset by immense challenges arising from this globalisation coinciding with demographic changes, changing governance and fast-evolving technology; reduction in or acute lack of funding; changes in the student population age profile, mode of study and learning styles; an increasing demand for client-oriented service (i.e., learner-centred education delivered 'anywhere, anytime, anyhow'); rising numbers of students due to internationalisation and growing demand for access to lifelong learning and professional development; changing policy environments; and evolving quality assurance frameworks and mechanisms, to mention but a few influential factors. In response, higher education options have already grown significantly in volume, diversity and form.

Demand for higher education continues to rise worldwide: current global enrolments of 165 million are forecast to grow by a further 98 million by 2025 (Commonwealth of Learning, 2011). However, tightening fiscal policy and the now widespread austerity measures resulting from the global financial crisis signify a shift in priorities that suggests an equivalent increase in available human and financial resources is unlikely to accompany the increased load. Innovation and collaboration are key in this new educational landscape. Open Educational Resources (OER) have captured the imagination of governments, policy-makers, funding bodies and educational institutions around the world as a potential solution. The OER movement is considered important in democratising education and promoting access to education for everyone, but particularly for non-traditional learners and the rising numbers needing education in developing countries, where it is evident that conventional approaches are not going to meet the needs of learners and educators (Butcher \& Housen, 2014, Caswell, Henson, Jensen, \& Wiley, 2008; D'Antoni, 2008; Daniel, 2011; Kanwar, Kodhandaraman, \& Umar, 2010a; Lane, 2008b). At a time when information literacy and effective use of knowledge are increasingly the key to both individual and national economic success, OER can also efficiently and efficaciously promote lifelong learning and bridge the gap between non-formal, informal and formal learning (OECD, 2007).

This Special Section focuses on OER initiatives in Broader Oceania, a region where few, if any, countries have been immune to the on-going turmoil besetting the higher education sector and where the weight of ever-increasing student demand coupled with declining resources is perhaps most heavily felt. In its broadest sense, Oceania includes the islands of the South Pacific scattered across Polynesia, Micronesia, Melanesia as well as Australia and New Zealand and the countries of the Malay Peninsula (Indonesia, Malaysia, Burma, Thailand, Cambodia, Vietnam, Philippines). This region is sufficiently diverse to offer opportunities for comparison, but with similarities that allow for constructive exchange of ideas. It includes large and small nations, with differing operational contexts, advantages, opportunities, challenges and constraints. Distance education is a priority area of cooperation and collaboration among many of the countries in this region and, despite the lack of supportive infrastructure in the majority, increasingly technology and online learning are being considered as a solution to the burden of growing student numbers and changing and often inadequate funding models. For similar reasons, there is also strong interest in OER across this region (Dhanarajan \& Porter, 2013).

RUSC VOL. 11 No 3 | Universitat Oberta de Catalunya and University of New England | Barcelona, July 2014 


\section{What are OER?}

Since its initial use by the United Nations Educational, Scientific and Cultural Organization (UNESCO) in 2002, the term "open educational resources" (UNESCO, 2002) has been re-defined several times to meet the fast-evolving pace of the movement and to fit with the diverse range of contexts in which it has been applied. Therefore, readers will find different OER definitions in the papers of this Special Section. However, the 2012 Paris Declaration on OER has developed the following definition of OER, currently adopted widely:

Teaching, learning and research materials in any medium, digital or otherwise, that reside in the public domain or have been released under an open license that permits no-cost access, use, adaptation and redistribution by others with no or limited restrictions (UNESCO, 2012, p. 1).

OER vary in size (from full courses to stand-alone learning objects) and type (from digital images, videos, podcasts to simply text and PDFs). "OER can also include simulations, virtual laboratories, collections, journals and tools" (Butcher \& Hoosen, 2014, p. 8).

The concepts of openness and sharing have long been on the education agenda, conspicuous in the establishment of open universities approximately 150 years ago. The meaning of 'open' has since evolved and, today, it goes beyond learning 'anywhere, anytime' and open entry and exit points, which were the foundations of open universities and their correspondence and distance education models. OER are part of a larger, rapidly growing movement to open up education. Other elements of this movement are open source software, open access (research and data), open design, open courseware, open educational practices and so forth (Butcher \& Hoosen, 2014). This Special Section covers several of these topics. Some of the drivers behind this movement are the desire to share content and knowledge freely in ways that prevent duplication and encourage economies of scale, as well as the need to increase access to education for a growing and diverse student cohort with minimum restriction (including in relation to copyright) (Commonwealth of Learning, 2011; The William and Flora Hewlett Foundation, 2013; Wiley \& Gurrell, 2009).

\section{OER in Higher Education}

In 2001, Massachusetts Institute of Technology (MIT) began a new trend in education by publishing open online courses (known as OpenCourseWare or OCW). This academic ambition for openness and sharing was formalised by adoption of the term "Open Educational Resources" in 2002 by UNESCO (UNESCO, 2002, p. 6), and the release of Creative Commons licenses provided a sense of unity of purpose that was the impetus for expansion of the OER movement, their greater flexibility giving new momentum to the creation of OER (Bissell, 2009).

Since then, there have been considerable developments and government investment in OER. By 2007, India had embraced OER, supported by government and external funds. The Netherlands followed, spending EUR 8 million on its national "Wikiwijs" programme from 2009-2013. The JISC and Higher Education Academic joint OER programme (2009-2013) in the United Kingdom was supported by public funding of more than GBP 13 million (http://www. heacademy.ac.uk/oer). Between 2011 and 2014, the US government invested USD 2 billion in a programme aimed at improving education at community colleges using OER. Poland began developing OER in 2012 as part of its 
EUR 13 million digital school programme. Indonesia is in the process of transitioning to an OER-based education system and similar initiatives have been introduced in Brazil, China, Korea, Slovenia, South Africa, Turkey and Vietnam (Butcher \& Hoosen, 2014; Dhanarajan \& Porter, 2013; Jacobi, Jelgerhuis, \& van der Woert, 2013). OER enjoy the spotlight at such organisations as UNESCO, COL, ICDE, the OECD and the European Union. Over the past few years especially, the OER movement has seen rapid development fuelled by beneficial technological advances and some highly visible developments in higher education globally, such as the wide adoption of UNESCO's Paris OER Declaration launched in June 2012 and the piquing of institutional interest with the advent of MOOCs.

Currently, there is a whole range of OER initiatives, projects and repositories available, from openly licensed videos (YouTube), photographs (Flickr) and open textbooks (Open Textbook Catalog, Flatworld Knowledge), to Learning Management Systems (Xerte), full courses (Khan Academy, P2PU) and lectures (Lecturefox), authoring and sharing applications (LeMill), to repositories of academic and government publications (OER Knowledge Cloud) and Open Access Journals (DOAJ), and much more. As mentioned above, there are major OER initiatives in every continent in the world. OER initiatives have not only increased in numbers, they have also evolved theoretically and ideologically. Examples of this evolution are Open Educational Practice (OEP) and Massive Open Online Courses (MOOCs). OEP is based on the principles that open content coupled with open pedagogy, open policies, open technologies and a range of other intuitional elements are likely to further encourage educational institutions to fundamentally embrace and establish effective open practices, instead of a narrow focus on OER (Conole, 2013). MOOCs are online courses offered free to learners around the world (Daniel, 2012). Initially, MOOC offerings were from some of the world's best universities (Wappett, 2012); today, there are more than 1,000 offerings from institutions worldwide targeting different fields of study and learner cohorts (Butcher \& Hoosen, 2014). While some MOOCs are truly 'open', use OER and connected and networked learning approaches (cMOOCs), the majority of them are 'free' online courses that tend to use more traditional behaviourist approaches to learning and teaching (xMOOCs) (Butcher \& Hoosen, 2014). Universities worldwide have realised the potential of MOOCs to attract students, to showcase their courses and to profit through coupling MOOCs with payment for learning assessment and credentialing (Caudill, 2012; Stacey 2012).

Despite the OER moment's rapid growth and its benefits to learners, educators and institutions, there remain a number of urgent issues that need to be resolved before OER can flourish. Regardless of the significant funding and engagement with various OER initiatives, overall, awareness about OER outside projects is still fairly limited (Bossu, Bull, \& Brown, 2012). In addition, issues related to copyright and intellectual property policies and a lack of incentives from institutions for staff to use and develop OER remain important institutional barriers to OER adoption (Atkins, Brown, \& Hammond, 2007; Bossu \& Tynan, 2011; Wiley \& Gurrell, 2009). So, have OER increased access, improved quality or cut costs, thus widening participation in higher education as envisaged? The result of the various previously-mentioned OER initiatives is that users can now access more than 350 million OER (Terasse, 2012) and over 1,000 MOOCs (Butcher \& Hoosen, 2014), but widening access (if indeed that has been achieved) is not necessarily any guarantee of improving learning. Furthermore, not all OER are widely or globally accessible in a pedagogical or technical sense: discoverability and accessibility of OER also depends on appropriate technical approaches, software and hosting choices, learning design and decisions about ownership and licencing.

There is little evidence of OER contributing to cost efficiencies. The value-cost ratio benefit of openly licensing educational resources is underpinned by an expectation of repurposing/remixing of OER. Academics report that the value of OER lies more in enabling them to enrich the learning experience, by supplementing their lack of requisite skills and technical resources to produce rich media resources, than in time or money savings from not developing resources themselves (McGill, Falconer, Littlejohn, \& Beetham, 2013). Even so, the low level of OER re-use

RUSC VOL. 11 No 3 | Universitat Oberta de Catalunya and University of New England | Barcelona, July 2014

@ Rosalind James and Carina Bossu |@FUOC, 2014 | Conversations from south of the equator: Challenges and Opportunities in OER across Broader Oceania 
has become a significant part of scholarly discussion. Despite the rhetoric, the reality is that OER uptake and re-use in formal educational contexts appears minimal.

As the OER movement matures, some of the challenges above will be addressed and overcome, others will turn into opportunities and some may disappear as the future trajectory of this movement and other developments in higher education emerge.

\section{Future trends in OER}

Much about OER is uncharted territory and trying to predict the future in these fast-changing times is a fraught affair. The emergence of OEP and MOOCs has broadened the discussion, bringing with them considerations of how they fit within both the wider open ecosystems and mainstream approaches to learning and teaching. OER have matured into a phase of addressing weaknesses and challenges in order to produce a better product. This maturity can be identified in recent initiatives and in the way some higher educational institutions are innovating and adapting themselves to this movement, some of which are demonstrated in the papers of this Special Section.

Creating quality and pedagogically-rich open learning experiences requires attention to instructional and learning design and reconsideration of our theoretical approaches to learning (Conole, 2013; Conole, de Laat, Dillon, \& Darby, 2008; Conole \& Weller, 2008; Weller, 2011). Two papers in this Special Section address different aspects of access in relation to design of learning in an OER context.

In the first, Open Educational Resources: A regional university's journey, Koroivulaono presents two case studies to highlight the development of OER and integration of Open Learning Design (OLD) principles and practices at the University of the South Pacific. The first aspect of access considered was connectivity: the results revealing that textbased content with very few or no images was easily accessed, but audio and video files proved problematic. The second case study of the effectiveness and appropriateness of an interactive audiovisual conference tool to enhance the learning experiences of distance students similarly showed that technical interruptions and quality of service concerns limited the learning experience for both students and academics in some contexts. Cost and reliability of Internet service have been shown to impact broadly across the Asia-Pacific (James, Tynan, Webster, Marshall, Suddaby, \& Lewis, 2012). These case studies provide examples of using research to gain specific knowledge of the learning context to inform learning design, infrastructure design, policy decisions, learning support provision and even forward strategic planning. They tackle the question of improving accessibility by looking at technical aspects of access and mitigation by the learning design, thus demonstrating the affordances of technology for learning design to enhance the student experience.

MOOCs have also impacted on the way traditional units/course/subjects and whole degrees are structured and designed. They have shifted the focus from providing OER for educators, with the emphasis being on the re-use of educational resources, to producing OER for learners, with the emphasis being on use. This trend will no doubt continue, but needs to extend to culturally sensitive OER development. As Koroivulaono points out, in many developing countries, access to ICT hardware, software and connectivity remain challenges; so it is critical to adapt pedagogical approaches and learning materials to this context to ensure high quality and relevant educational opportunities for learners (Willems \& Bossu, 2012).

Another aspect of accessibility is presented in 'Fit for Purpose': a cohort-centric approach to MOOC design, where King, Doherty, Kelder, Mclnerney, Walls, Robinson, and Vickers wrestle with a concern that has long vexed distance

RUSC VOL. 11 No 3 | Universitat Oberta de Catalunya and University of New England | Barcelona, July 2014

@a) Rosalind James and Carina Bossu | @ FUOC, 2014 | Conversations from south of the equator: Challenges and Opportunities in OER across Broader Oceania 
educators: how to adequately support independent, online learning scaled to a MOOC context with a target audience expected to lack critical literacies. Understanding that support by more knowledgeable others has proved helpful in this respect (Kop, 2011), King et al. adopt a model combining acquisition and participation - an approach that embraces Sfard's (1998) suggestion that learners engage with knowledge through acquisition (i.e., acquiring knowledge, pre-packaged by educators, as in behaviourist and cognitive theories) and participation (related to situated and social theories, such as social constructivism, action theory, connectivist developmental theories (Kop \& Hill, 2008) and communities of practice). This model and the various accommodations of the learning design achieved a completion rate higher than usual in MOOCS, so it will be interesting to better understand the relative contribution of the various elements (different cohort profile, learner motivation, learning design, etc.) as further analyses from this research become available.

These first two papers demonstrate that learning design can take place at macro, meso and micro levels (from specific learning activity to curriculum development) and has an important role throughout the teaching and learning cycle, from design and production, through delivery, to evaluation and sharing practice.

Propelled by increased demand for informal education, lifelong learning and abundance of open content (OER) and free online course (MOOCs), we have also recently seen a growing interest in Prior Learning Assessment Recognition (PLAR), assessment for accredited learning and the different pathways to a tertiary degree available to students (Bossu, Brown, \& Bull, 2014). This trend is likely to continue and gain traction as more institutions recognise the opportunity to attract a diverse cohort of students. The issue of accreditation is still very much unresolved, but avenues for accreditation or the validation of skills and competences acquired through studying informally and through adopting new awards and recognition systems (e.g., unbundling of services and badges) are being investigated by many education providers (Butcher \& Hoosen, 2014; Conrad, Mackintosh, McGreal, Murphy, \& Witthaus, 2013). There are currently no formal quality standards for OER so quality assurance remains a pressing issue.

Factors such as increasing transparency and citizen engagement have motivated the drive to open data. Many countries worldwide (mostly developed nations) are adopting open access policies. These policies promote the publication of government-funded research data and outputs under open licenses, most commonly Creative Commons licenses. In The evolution of open access to research and data in Australian higher education,_Picasso and Phelan explore issues and implications related to policies for open access to research and scholarly outputs in higher education in Australia and worldwide, tracking developments over the last 15 years. They argue that it is just a matter of time before similar policies and developments will be applied to educational content developed using public money. This is also an approach that acknowledges the dividends from leveraging taxpayer-funded educational developments for the benefit of a much wider audience (Kanwar, Kodhandaraman, \& Umar, 2010b). This trend is certainly gaining momentum as more and more nations believe that "opening up their resources and works for re-use will promote more open and transparent government" (Bossu et al., 2014, p. 18). As a consequence, educational institutions have been encouraged to review and/or develop their policies to reflect these transitions in government priorities. In Australia, for example, several universities have their intellectual property policies currently under review to meet recent government policy changes (Scott, 2013). As mentioned earlier and, also, demonstrated by Hannon, Huggard, Orchard, and Stone in OER in practice: Organisational change by bootstrapping, these policies play an important role in promoting and encouraging an institutional environment in which OEP can flourish. Three short case studies are presented to explore emergent OER and OEP adoption at La Trobe University, Australia. These bottom-up developments, arising from grassroot beginnings rather than embedded in a larger OER project or national initiative or a top-down programme, have initiated OEP as part of institutional academic culture.

RUSC VOL. 11 No 3 | Universitat Oberta de Catalunya and University of New England | Barcelona, July 2014

@ Rosalind James and Carina Bossu |@ FUOC, 2014 | Conversations from south of the equator: Challenges and Opportunities in OER across Broader Oceania 
As OER and its derivatives (OEP and MOOCs) are only in the early stages of development compared with related study areas, our understanding of their impact on learning and teaching and on educational organisations as a whole is limited. Therefore, further research is needed to expand the opportunities and possibilities of OER. Smith (2013), supported by the William and Flora Hewlett Foundation, has identified "nine areas of research on OER from policy to development and its relative effectiveness and whether it stimulates innovation" (Smith, 2013, p. 1). The nine areas or "nine research buckets" are: policy research, access and use, effectiveness, innovation, beyond formal education, sustainability, development and improvement, implementation, and infrastructure (Smith, 2013, pp. 4-5). He also states that, depending on the research questions and researchers' orientations (ontology and epistemology), some of the areas can overlap and fit in more than one bucket. In OER adoption: a continuum for practice ${ }_{L}$ Stagg provides an example of a study that can fit in multiple research "buckets": access and use; development and improvement; and implementation. This last paper in our Special Section also considers the attitudinal shift from open resources to open practice and the interplay between practitioner experience and the institutional environment. By understanding practitioner motivations and their experience of contextually reusing, revising, remixing, and redistributing OER to support learning outcomes, Stagg proposes a continuum to characterise adoption of OEP by academics, taking into consideration institutional factors that can hinder/inhibit adoption.

One last future trend in OER requires comment: the emergence of different business models for higher education. The current abundance of online, open and free course and content shifts some of the educational values previously based on scarcity of resources (Weller, 2011). The growing availability of cheaper and faster Internet connections and more learning technologies has made access to OER much easier and more wide-spread. Informal learning through OER, MOOCs and other free and open courses has pushed universities to consider different accreditation models and disaggregation (or unbundling) of services, which again challenges the core business of a university. Butcher and Hoosen $(2014$, p.13) suggest that "institutions will need to decide what role they are going to play in higher education and innovation and may need to become open service providers to maintain their positions. The educational focus of institutions will tighten so that they make more efficient use of the resources they have". However, the reality today is that many OER initiatives are based on an altruistic notion of opening resources worldwide and, having been established with 'one-off' initial funding will struggle to support total cost of ownership, including the costs of support and upgrades over time, and transition to a future independent of foundation funding. New business models will certainly emerge, but current business models for OER (Downes, 2007; Lane, 2008a) are in their infancy, and whether any institution pursues models based on the various options, such as the sale of services and accreditation, OER as a reputation builder or OER as a means of enhancing recruitment via'showcasing' will be highly dependent on any given institution's overarching mission and business strategy (Bossu \&Tynan, 2011).

\section{Conclusions}

Equity of access to education is no timid vision and no doubt will, therefore, require audacious solutions and outof-the-box thinking. Some of the critical questions are so large and complex, it is unlikely that there will be any immediate resolution, but, as educators, we should not shrink from the challenge. OER, OEP and the Open Education vision have great potential to provide solutions to existing educational problems, but sustainable business models,

RUSC VOL. 11 No 3 | Universitat Oberta de Catalunya and University of New England | Barcelona, July 2014

@ Rosalind James and Carina Bossu |@ FUOC, 2014 | Conversations from south of the equator: Challenges and Opportunities in OER across Broader Oceania 
increased awareness, digital literacies up-skilling, appropriate policies and accreditation systems are key issues to be overcome to safeguard continuity in OER development and use. Since OER adoption is currently modest in scale, the long-term consequences of OER and OEP will play out over the next several years as learner interest in open content continues to increase, and educators begin to adapt to this trend. In fact, we believe that the real value and power of OER will be realised when learners, rather than taking products assembled and organised by someone else, begin to appropriate the multitude of material already freely available over the Internet (although not necessarily labelled as OER) for designing their own personalised content and learning pathways, and education providers are forced to find a way to give formal recognition to this learning.

We hope that you find this Special Section interesting, informative and relevant, whether you are an OER advocate, an inquisitive researcher learning about OER, an educator passionate about learning and teaching or a senior executive interested in the topic - we hope to present something of interest for everyone. Enjoy the reading!

\section{Acknowledgements}

We would like to thank RUSC. Universities and Knowledge Society Journal for the invitation to be the guest editors for this Special Section. We would also like to thank the authors and the invited reviewers for their generous collaboration and support in this issue. We are indebted to the Managing Editor, Ms Elsa Corominas Rodríguez, for her expert guidance, encouragement and good humour throughout the review and editing process.

\section{References}

Atkins, D., Brown, J., \& Hammond, A. (2007). A review of the Open Educational Resources (OER) movement: achievements, challenges, and new opportunities. Report to the William and Flora Hewlett Foundation. Retrieved from http:// www.hewlett.org/uploads/files/ReviewoftheOERMovement.pdf

Bissell, A. N. (2009). Permission Granted: Open Licensing for Educational Resources. Open Learning, 24(1), 97-106. doi http://dx.doi.org/10.1080/02680510802627886

Bossu, C., Brown, M., \& Bull, D. (2014). Adoption, use and management of Open Educational Resources to enhance teaching and learning in Australia. Sydney, Australia: Australian Government Office for Learning and Teaching.

Bossu, C., Bull, D., \& Brown, M. (2012). Opening up Down Under: the role of open educational resources in promoting social inclusion in Australia. Distance Education, 33(2), 151-164. doi http://dx.doi.org/10.1080/01587919.2012.69 2050

Bossu, C., \&Tynan, B. (2011). OERs: new media on the learning landscape. On the Horizon, 19(4), 259-267. doi http:// dx.doi.org/10.1108/10748121111179385

Butcher, N., \& Hoosen, S. (2014). A Guide to Quality in Post-Traditional Online Higher Education. In J. Daniel \& S. Uvalić-Trumbić (Eds.). Dallas, Academic Partnerships.

Caswell, T., Henson, S., Jensen, M., \& Wiley, D. (2008). Open educational resources: Enabling universal education. International Review of Research in Open and Distance Learning, 9(1), 1-4.

Caudill, J. (2012). Open, Closed, or Something Else?: The Shift of Open Educational Resources to Credentialed Learning. DEQuarterly, 12, 2-3.

RUSC VOL. 11 No 3 | Universitat Oberta de Catalunya and University of New England | Barcelona, July 2014

@ Rosalind James and Carina Bossu | @ FUOC, 2014 | Conversations from south of the equator: Challenges and Opportunities in OER across Broader Oceania 
Commonwealth of Learning (2011). Guidelines for Open Educational Resources (OER) in Higher Education. Paris, France/ Vancouver, Canada: UNESCO/Commonwealth of Learning.

Conole, G. (2013). Designing for learning in an open world (Vol. 4). New York, NY: Springer. doi http://dx.doi. org/10.1007/978-1-4419-8517-0

Conole, G., de Laat, M., Dillon, T., \& Darby, J. (2008). 'Disruptive technologies', 'pedagogical innovation': What's new? Findings from an in-depth study of students' use and perception of technology. Computers \& Education, 50, 511524. doi http://dx.doi.org/10.1016/j.compedu.2007.09.009

Conole, G., \&Weller, M. (2008). Using Learning Design as a Framework for Supporting the Design and Reuse of OER. Journal of Interactive Media in Education, 5.

Conrad, D., Mackintosh, W., McGreal, R., Murphy, A., \& Witthaus, G. (2013). Report on the assessment and accreditation of learners using OER. Retrieved from http://www.col.org/PublicationDocuments/Assess-Accred-OER_2013.pdf..

D'Antoni, S. (2008). Open Educational Resources: The Way Forward. Deliberations of an International Community of Interest. Paris, France: UNESCO International Institute on Educational Planning (IIEP).

Daniel, J. (2011, March). Revolutions in higher education: How many dimensions of openness? The Ernest Boyer Lecture. Speech presented at Empire State College, State University of New York. Retrieved from http://www.col. org/resources/speeches/2011 presentation/Pages/2011-03-23.aspx

Daniel, J. (2012). Making Sense of MOOCs: Musings in a Maze of Myth, Paradox and Possibility. Fellow of the Korea National Open University. Research Paper Retrieved from http://sirjohn.ca/wordpress/wp-content/uploads/201 2/08/120925MOOCspaper2.pdf

Downes, S. (2007). Models for Sustainable Open Educational Resources. Interdisciplinary Journal of E-Learning and Learning Objects, 3, 29-44.

Gajaraj Dhanarajan, G., \& Porter, D. (Eds.) (2013). Perspectives on Open and Distance Learning: Open Educational Resources: An Asian Perspective. Vancouver, Canada: Commonwealth of Learning and OER Asia.

Jacobi, R., Jelgerhuis, H., \& van der Woert, N. (Eds.) (2013). Trend Report: Open Educational Resources 2013. Retrieved from http://www.surf.nl/en/publicaties/Documents/Trend\%20Report\%200ER\%202013_EN_DEF\%20 07032013\%20\%28HR\%29.pdf

James, R., Tynan, B., Webster, L., Marshall, S., Suddaby, G., \& Lewis, R. (2012) Regulatory Frameworks for distance education in the Southwest Pacific/South East Asia region: similarities and differences. Unpublished report to ICDE, Oslo, Norway. Retrieved from http://www.icde.org/en/icde_news/The+Regulatory+Frameworks+for+Distance +Education.b7C_wJVQ2Z.ips

Kanwar, A., Kodhandaraman, B., \& Umar, A. (2010a). Toward Sustainable Open Education Resources: A Perspective From the Global South. American Journal of Distance Education, 24(2), 65-80. doi http://dx.doi. org/10.1080/08923641003696588

Kanwar, A., Kodhandaraman, B., \& Umar, A. (2010b). Toward Sustainable Open Education Resources: A Perspective From the Global South. American Journal of Distance Education, 24(2), 65-80. doi http://dx.doi. org/10.1080/08923641003696588

Lane, A. (2008a). Reflections on Sustaining Open Educational Resources: An Institutional Case Study. eLearning Papers, (10), 1-13.

Lane, A. (2008b). Widening participation in education through open educational resources. In T. liyoshi \& M. S. Vijay Kumar (Eds.), Opening up education: The collective advancement of education through open technology, open content and open knowledge (pp. 149 - 163). Cambridge, MA: The MIT Press. 
McGill, L., Falconer, I., Littlejohn, A., \& Beetham, H. (2013). J/SC/HE Academy OER Programme: Phase 3 Synthesis and Evaluation Report. JISC, February 2013. Retrieved from https://oersynth.pbworks.com/w/page/59707964/ ukoer3FinalSynthesisReport

OECD. (2007). Giving knowledge for free: The emergence of open educational resources. Paris, France: OECD Publishing.

Scott, B. (2013). Supporting OER engagement at Australian Universities: An overview of the intellectual property rights, copyright and policy considerations for OER. Retrieved from http://new.dehub.edu.au/wp-content/ uploads/2013/07/IPCopyright-for-OER-in-Australia-Final-Version-13Mar2013.pdf

Sfard, A. (1998). On two metaphors for learning and the dangers of choosing just one. Educational Researcher, 27(2) 4-13. doi http://dx.doi.org/10.3102/0013189X027002004

Smith, M. (2013). Ruminations on Research on Open Educational Resources. William and Flora Hewlett Foundation. Retrieved from http://www.hewlett.org/sites/default/files/OER\%20Research\%20paper\%20December\%20 15\%202013\%20Marshall\%20Smith_1.pdf

Stacey, P. (2012, March 4). The Economics of Open [Web log post]. Retrieved from http://edtechfrontier. com/2012/03/04/the-economics-of-open/

Terasse, C. (2012, September 10). Open Educational Resources-the future of learning? [Web log post]. Retrieved from http://www.eaie.org/blog/open-educational-resources-the-future-of-learning/

The William and Flora Hewlett Foundation (2013). White Paper: Open Educational Resources - Breaking the Lockbox on Education. Retrieved from http://www.hewlett.org/sites/default/files/OER\%20White\%20Paper\%20Nov\%20 22\%202013\%20Final.pdf.

UNESCO (2002). Forum on the Impact of Open Courseware for Higher Education in Developing Countries. Final Report. Paper presented at the Forum on the Impact of Open Courseware for Higher Education in Developing Countries. UNESCO, Paris, France. 1-3 July 2002., UNESCO, Paris, France.

UNESCO (2012). 2012 Paris Open Declaration. Paper presented at the World Open Educational Resources (OER) Congress, Paris, France. http://www.unesco.org/new/fileadmin/MULTIMEDIA/HQ/CI/CI/pdf/Events/Paris\%20 OER\%20Declaration_01.pdf

Wappett, P. (2012, October 11). Radical rethink: how to design university courses in the online age. The Conversation. Retrieved from http://theconversation.edu.au/radical-rethink-how-to-design-university-courses-in-the-onlineage-9737

Weller, M. (2011). A pedagogy of abundance. Spanish journal of pedagogy, 249, 223-236.

Wiley, D., \& Gurrell, S. (2009). A Decade of Development. Open Learning: The Journal of Open, Distance and e-Learning, 24(1), 11-21. doi http://dx.doi.org/10.1080/02680510802627746

Willems, J., \& Bossu, C. (2012). Equity considerations for open educational resources in the glocalization of education. Distance Education, 33(2), 185-199. doi http://dx.doi.org/10.1080/01587919.2012.692051 


\section{About the authors}

Rosalind James

directordehub@une.edu.au

Director, dehub

Director, Research Fellow, School of Education, University of New England, Australia

Dr Rosalind James is the director of dehub: Innovation in distance education. Dr James has worked with dehub since before its inception, having assisted to write the grant for funding, and at the University of New England (UNE), Australia, for many years, as a Research Fellow with dehub and with Project 2012: Flexible and Online. Prior to dehub, Dr James was a course coordinator and lecturer on the foundational pathway course in UNE's Teaching and Learning Centre (TLC) and an academic mentor for transitional students. Like many in the distance education field, Rosalind comes from a strong background established in other disciplines. She has been an archaeological consultant and a lecturer in Archaeology and Environmental Science, and has worked in diverse companies and government departments around the world as a senior manager and technical information and communications technology (ICT) consultant in the commercial ICT arena. Her current research and publications interest is in the implementation and integration of ICT in learning in general, and Web 2.0 and social networking technologies in particular. She is also interested in business use of technology and its implications for graduate attributes and professional development for academics teaching by distance. Other projects directed by Dr James include the ICDE's Regulatory Frameworks for Distance Education in the Southwest Pacific/South East Asia region and a large collaborative project to develop eduONE, a community education portal offering Open Educational Resources for lifelong learning.

Rm 3.3, PDAL Building No17, Clark's Farm Road

University of New England, NSW 2351

Australia

\section{Carina Bossu}

Carina.Bossu@utas.edu.au

Lecturer (Learning and Teaching), Tasmanian Institute of Learning and Teaching, University of Tasmania, Australia

Dr Carina Bossu is a lecturer (Learning and Teaching) with the Tasmanian Institute of Learning and Teaching (TILT) at the University of Tasmania (UTAS), Australia. Her current work and research are primarily focused on Open Educational Resources (OER) and Open Educational Practices (OEP) in higher education, more specifically issues related to learning, teaching and professional development. Previously, she was a Research Fellow with dehub at the University of New England (UNE), Australia, where her role was to investigate the use and adoption of OER across the Australian higher education sector. In 2013, Carina was named the New Researcher "One to Watch" of the year by Routledge Education. Dr Bossu has presented and published widely and is currently involved in several research projects and supervision teams investigating different aspects of OER and OEP in higher education.

Tasmanian Institute of Learning and Teaching

DVC, Students and Education

University of Tasmania

Private Bag 133, Hobart TAS 7001

Australia

RUSC VOL. 11 No 3 | Universitat Oberta de Catalunya and University of New England | Barcelona, July 2014 
The texts published in this journal are - unless indicated otherwise - covered by the Creative Commons Spain Attribution 3.0 licence. You may copy, distribute, transmit and adapt the work, provided you attribute it (authorship, journal name, publisher) in the manner specified by the author(s) or licensor(s). The full text of the licence can be consulted here: <http://creativecommons.org/licenses/by/3.0/es/deed.en>

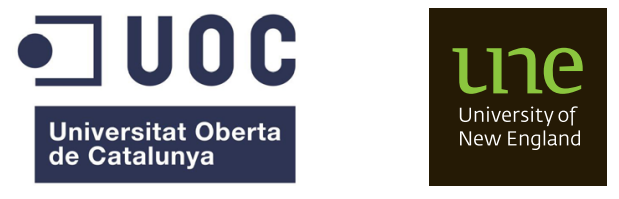

